Article

\title{
A Terrestrial Single Chamber Microbial Fuel Cell-based Biosensor for Biochemical Oxygen Demand of Synthetic Rice Washed Wastewater
}

\author{
Washington Logroño ${ }^{1,2, *,+}$, Alex Guambo ${ }^{1}$, Mario Pérez ${ }^{1}$, Abudukeremu Kadier ${ }^{3}$ and \\ Celso Recalde ${ }^{1,4,+}$ \\ Received: 10 November 2015; Accepted: 11 January 2016; Published: 15 January 2016 \\ Academic Editor: I-Ming Hsing \\ 1 Centro de Investigación de Energías Alternativas y Ambiente, Facultad de Ciencias, Escuela Superior \\ Politécnica de Chimborazo (ESPOCH), Panamericana Sur Km 1 1⁄2, Chimborazo EC060155, Ecuador; \\ alexfernag@gmail.com (A.G.); map_1090@hotmail.com (M.P.); crecalde672000@yahoo.com (C.R.) \\ 2 Faculty of Science and Informatics, University of Szeged, Közép fasor 52, Szeged H-6726, Hungary \\ 3 Department of Chemical and Process Engineering, Faculty of Engineering \& Built Environment, \\ National University of Malaysia (UKM), UKM Bangi, Selangor 43600, Malaysia; abudoukeremu@163.com \\ 4 Escuela de Ingeniería Ambiental, Universidad Nacional de Chimborazo, Chimborazo EC060103, Ecuador \\ * Correspondence: logrono.w@gmail.com; Tel.: +36-30-757-4843 \\ + These authors contributed equally to this work.
}

\begin{abstract}
Microbial fuel cells represent an innovative technology which allow simultaneous waste treatment, electricity production, and environmental monitoring. This study provides a preliminary investigation of the use of terrestrial Single chamber Microbial Fuel Cells (SMFCs) as biosensors. Three cells were created using Andean soil, each one for monitoring a BOD concentration of synthetic washed rice wastewater (SRWW) of 10, 100, and $200 \mathrm{mg} / \mathrm{L}$ for SMFC1, SMFC2 and SMFC3, respectively. The results showed transient, exponential, and steady stages in the SMFCs. The maximum open circuit voltage (OCV) peaks were reached during the elapsed time of the transient stages, according to the tested BOD concentrations. A good linearity between OCV and time was observed in the increasing stage. The average OCV in this stage increased independently of the tested concentrations. SMFC1 required less time than SMFC2 to reach the steady stage, suggesting the BOD concentration is an influencing factor in SMFCs, and SMFC3 did not reach it. The OCV ratios were between $40.6-58.8 \mathrm{mV}$ and 18.2-32.9 $\mathrm{mV}$ for SMFC1 and SMFC2. The reproducibility of the SMFCs was observed in four and three cycles for SMFC1 and SMFC2, respectively. The presented SMFCs had a good response and reproducibility as biosensor devices, and could be an alternative for environmental monitoring.
\end{abstract}

Keywords: microbial fuel cell; biological oxygen demand (BOD); biosensor

\section{Introduction}

Microbial fuel cells (MFCs) are an innovative technology due to their versatile and promising environmental applications such as bioremediation [1], as biosensors [2,3], for wastewater treatment $[4,5]$ and for supplying energy for small devices [3,4]. The MFC is a bio-electrochemical device that converts organic substrates into electricity through the metabolism of electrochemically active microorganisms [5,6]. The process into an MFC is as follows: (a) the organic compounds are oxidized in the anode chamber of the MFC; (b) electrons produced by microorganisms are transferred to the anode electrode and subsequently to the cathode electrode through an external circuit; (c) protons are diffused across the proton exchange membrane (PEM) from the anode to the cathode chamber; and 
(d) protons and electrons react with atmospheric oxygen for the electrochemical balance in the cathode chamber by forming $\mathrm{H}_{2} \mathrm{O}$. MFCs can be configured as a double or single chamber device, and can be inoculated with sediment, soil or wastewater. Pure and mixed cultures have been tested in the MFC technology, which may metabolize a small and wide range of substrates, respectively.

Biological oxygen demand (BOD) is a well-known indicator of water quality. The BOD refers to the amount of oxygen needed by microorganisms to oxidize the organic matter present, and conventionally is analyzed by the standard methods of the U.S. Environmental Protection Agency [7]; however, it is a time consuming method [8].

MFC-based biosensors have been tested for monitoring volatile fatty acids [9], COD [10], chromium, iron, nitrate, sodium acetate [11], toxic components [12], anaerobic digestion processes [13], biodegradable organic matter [14], BOD [15], water quality cadmium [16] and Cu (II) [17]. At the same time, MFC-based biosensors have limitations for commercial application due to the unavailability of standardized bacterial mixtures, although a known bacterial mixture has been used for measuring BOD in wastewater showing a good accuracy and reproducibility [8]. Although the lower current output of MFCs is recognized as a limiting factor for their application, an energy management system for amplifying the voltage up to $5 \mathrm{~V}$ was reported [18]. Addionally, mixed cultures from wetland soils have also been used to degrade complex organic substrates considering their higher metabolic activity, where the output voltages were acceptable according to the reported in databases [19,20].

This study tested if soil microorganisms from the Andean wetlands can respond in terrestrial single chamber microbial fuel cells (SMFCs)-based biosensors to BOD concentrations of SRWW, through the bioelectricity generation performance. Data were collected over a testing time of $15 \mathrm{~d}$, looking for the feasibility for reaching the early steady stage of this kind of MFC as a biosensor.

\section{Experimental Section}

\subsection{Experimental Setup}

Andean soil has previously been used for inoculating MFCs to generate bioenergy by using organic solid wastes as a microbial fuel. The microbial inoculum was determined to be a mixed consortium, sampled from undisturbed Andean soils at $3850 \mathrm{~m}$ above sea level (masl); $763138 \mathrm{~W}-9833826 \mathrm{~N}$, and collected between 20 to $40 \mathrm{~cm}$ depth [20]. The soil used in this study presented the following characteristics: pH 5.4, organic matter $2.0 \%$, electrical conductivity $170 \mu \mathrm{S}$, ammonia nitrogen $9.1 \mathrm{mg} / \mathrm{L}$, phosphorous $40.3 \mathrm{~g} / \mathrm{L}$ and potassium $0.96 \mathrm{mg} / \mathrm{L}$. A contrast of physico-chemical properties was done between the present and previous studies, and most of the parameters were within the same range. Colony forming units (CFU/g soil) were determined according to Logroño et al. [20]. Although, the same soil was used for assembling all SMFCs, the initial CFU/g soil counts were determined to be $3.3 \times 10^{9}, 5.0 \times 10^{9}$ and $5.0 \times 10^{8} \mathrm{CFU} / \mathrm{g}$ soil for SMFC1, SMFC2 and SMFC3, respectively. The microbial population and diversity of the SMFCs were supposed to be different. This factor limited any further comparison between OCV and BOD concentration tested in the cells.

\subsection{MFC Assembly and Monitoring}

Three independent SMFCs were simultaneously installed at the ESPOCH Biotechnology Lab, where the temperature fluctuated between 25 to $28^{\circ} \mathrm{C}$ and altitude was 2700 masl. The cells were made of polyethylene containers of $3900 \mathrm{~cm}^{3}$ volume. Figure 1 depicts a scheme of the SMFCs tested. The inlet port was installed in the anode chamber for wastewater feeding. The anode chamber was filled with $2.1 \mathrm{~kg}$ of soil, where the soil microorganisms metabolized the wastewater, producing electrons and protons. The SMFCs employed a blend of soil-activated carbon as membrane, $2.1 \mathrm{~kg}$ and $120 \mathrm{~g}$, respectively. Both, anode and cathode electrodes were made of carbon fiber ( $300 \mathrm{~mm} \times 250 \mathrm{~mm}$ ), keeping them equal in the SMFCs, and the distance among them was $50 \mathrm{~mm}$. The anode and cathode were connected with two iron wires forming an external circuit. The OCV was measured by using a DT-832 digital multimeter $[18,19]$. The oxidant $\left(\mathrm{O}_{2}\right)$ in the cathode was supplied from the atmosphere 
during the elapsed time of the experiment. Data were collected for $90 \mathrm{~min}$, every $5 \mathrm{~min}$ after inoculation of SRWW for over a testing time of $15 \mathrm{~d}$ (considering each day as an independent cycle).

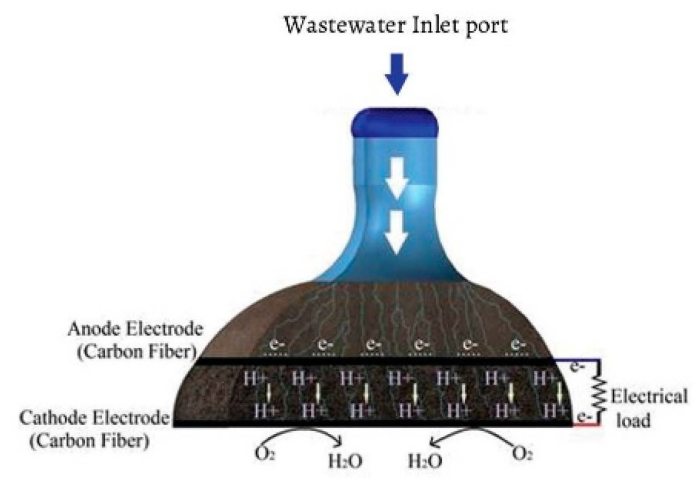

Figure 1. Schematic of the SMFCs installed for BOD monitoring.

\subsection{Wastewater Preparation and Inoculation}

Three BOD concentrations of SRWW were prepared by washing two types of commercial rice (A, B) with mineral water (MW; Tesalia Springs Company, Riobamba, Ecuador). The SRWW was analyzed as shown in Table 1. The composition of MW was as follows: $\mathrm{Ca}^{2+} 22 \mathrm{mg} / \mathrm{L}, \mathrm{Mg}^{2+} 58 \mathrm{mg} / \mathrm{L}$, $\mathrm{Na}^{+} 51 \mathrm{mg} / \mathrm{L}, \mathrm{P}^{+} 5.2 \mathrm{mg} / \mathrm{L}, \mathrm{HCO}_{3}{ }^{-} 380 \mathrm{mg} / \mathrm{L}, \mathrm{SO}_{4}{ }^{2-} 27 \mathrm{mg} / \mathrm{L}, \mathrm{Cl}^{-} 32 \mathrm{mg} / \mathrm{L}, \mathrm{DS} 440 \mathrm{mg} / \mathrm{L} . \mathrm{MW}$ alone was supplied in the control SMFC.

The commercial rice B was better than A for reaching constant BOD concentrations of 10, 100 and $200 \mathrm{ppm}$ during the experimentation. Each SMFC tested one independent concentration. Due to the fact the $\mathrm{pH}$ and BOD might change during the time; the SRWW supplied into the SMFCs was renewed in each independent cycle during the elapsed time of $15 \mathrm{~d}$. Effects of different $\mathrm{pH}$ of SRWW were not studied in the presented article.

The feed rate should be well below the fuel saturation conditions, because a high feed rate causes incomplete fuel consumption. On the other hand, the oxidant supply can limit the cathode reaction [21]. Thereby, in this study the Andean soil inside the SMFCs was saturated with SRWW at a feed rate of $94 \mathrm{~mL}$ every $24 \mathrm{~h}$ in order to avoid overflowing or supersaturation of the SMFC matrix. The SRWW descended by gravity from the anode to the cathode.

Table 1. Biochemical Oxygen Demand concentrations in the SRWW.

\begin{tabular}{cccc}
\hline SMFC & Mixing Time (min) & Concentration $(\mathbf{p p m})$ & Analytical Method \\
\hline SMFC1 & 5 & $10(1000 \mathrm{~mL}$ of MW $+14.175 \mathrm{~g}$ rice $)$ & Standard Method PEE/LS/CF $/ 01$ \\
SMFC2 & 5 & $100(1000 \mathrm{~mL}$ of MW $+56.7 \mathrm{~g}$ rice $)$ & Standard Method PEE/LS/CF/01 \\
SMFC3 & 5 & $200(1000 \mathrm{~mL}$ of MW $+226.8 \mathrm{~g}$ rice $)$ & Standard Method PEE/LS/CF $/ 01$ \\
\hline
\end{tabular}

\section{Results and Discussion}

Electricity generation and reproducibility was achieved in SMFCs while SRWW was inoculated as carbon source (the effect of different wastewaters was not studied). During the elapsed time of $15 \mathrm{~d}$ (15 cycles) three major stages of OCV output were observed in the SMFCs: transient, linearly increasing and steady; then we related it with the microbial growth curve, latency, exponential and stationary, respectively. Good linearity between current and BOD in MFCs inoculated with concentrations higher than $100 \mathrm{mg} / \mathrm{L}$, as reported by Chang et al. [15] was not been observed. Likewise, in this study only SMFC1 (10 ppm) and SMFC2 (100 ppm) reached the steady stage, each one on different days; suggesting that BOD concentration could be an influencing factor. Starch was considered to be the main compound and the electron donor of the SRWW in the SMFCs, therefore Equation (1) could illustrate the reactions involved in the SMFCs. Due to the fact the SMFCs in this study were inoculated 
with soil, the OCV could be generated by extracellular electron transfer [22], and such mechanisms have been reported for soil bacteria belonging to Proteobacteria and Firmicutes phylum [23]:

$$
\mathrm{C}_{6} \mathrm{H}_{10} \mathrm{O}_{5}+7 \mathrm{H}_{2} \mathrm{O} \rightarrow 6 \mathrm{CO}_{2}+24 \mathrm{H}^{+}+24 e^{-}
$$

OCV showed a highly variable transient trend named Phase 1 . The period of the transient stage was the same for all SMFCs (7 d), but each one behaved independently, likely due to the fact the effectbes consume the only carbon source in the soil. ed and lacking of carbon source decline twice the OCV detected foinitial microbial cultures showed differences between the CFU/g soil of SMFC1, SMFC2 and SMFC3, and such an effect could be explained by the microbial community variability at the particle size level in the soil [21]. By inoculating the SRWW, initial OCVs of 29.8, 149.5 and $179.6 \mathrm{mV}$ were immediately generated for SFMC1, SMFC2 and SMFC3, respectively. The difference of potential between anode and cathode based on chemical and biological factors could explain this well [24]. The minimum and maximum OCV reached during the transient stage were 0.9-90.7, 9.6-149.5 and 0.3-179.6 $\mathrm{mV}$ for SMFC1, SMFC2 and SMFC3, respectively. The initial and highest peak reached in each SMFC were in accordance with the BOD concentration. In the SMFCs is was also observed that BOD concentration had a major influence on the OCV during the transient stage until day 7; although the OCV ratio is lower in between 5-7 d, afterwards an increasing stage was observed. Such an effect could be explained as the required period for adaptation of the microorganisms to the new conditions in the SMFCs [19,20], an endogenous metabolism as reported Chang et al. [15] and the latency stage of the microbial growth related with the bioelectrogenic process. The high variability could also be related with the formation of microchannels in the soil matrix through which the SRWW was flowing during this stage, however, this effect was not studied in depth.

In the increasing stage (Phase 2) an independent period of linearity between OCV and time was observed in the SMFCs, with a $R^{2}$; of $0.77,0.63$ and 0.72 for SMFC1, SMFC2 and SMFC3, respectively (Figure 2), likely due to enrichment and biofilm formation on the anode electrode. The mean OCV of the minimum and maximum values of this stage increased from $3.04 \pm 1.82 \mathrm{mV}$ to $26.63 \pm 2.16 \mathrm{mV}$ (SMFC1), $2.79 \pm 1.87 \mathrm{mV}$ to $21.86 \pm 3.26 \mathrm{mV}$ (SMFC2), $2.65 \pm 2.02 \mathrm{mV}$ to $86.14 \pm 3.44 \mathrm{mV}$ (SMFC3), and $16.65 \pm 9.50 \mathrm{mV}$ to $34.70 \pm 2.00 \mathrm{mV}$ (SMFC-control). Furthermore, the ratios of the growing OCV were independent of the amount of microorganisms in the SMFCs (data not shown). In this stage the OCV of the SMFC control, was in a higher ratio than the others, highlighting that the SRWW BOD could influence the OCV output of the other SMFCs in this stage. It also indicates that the microbial community of the Andean soil was the responsible of the electrical response of the SMFCs devices while only consuming the soil nutrients.

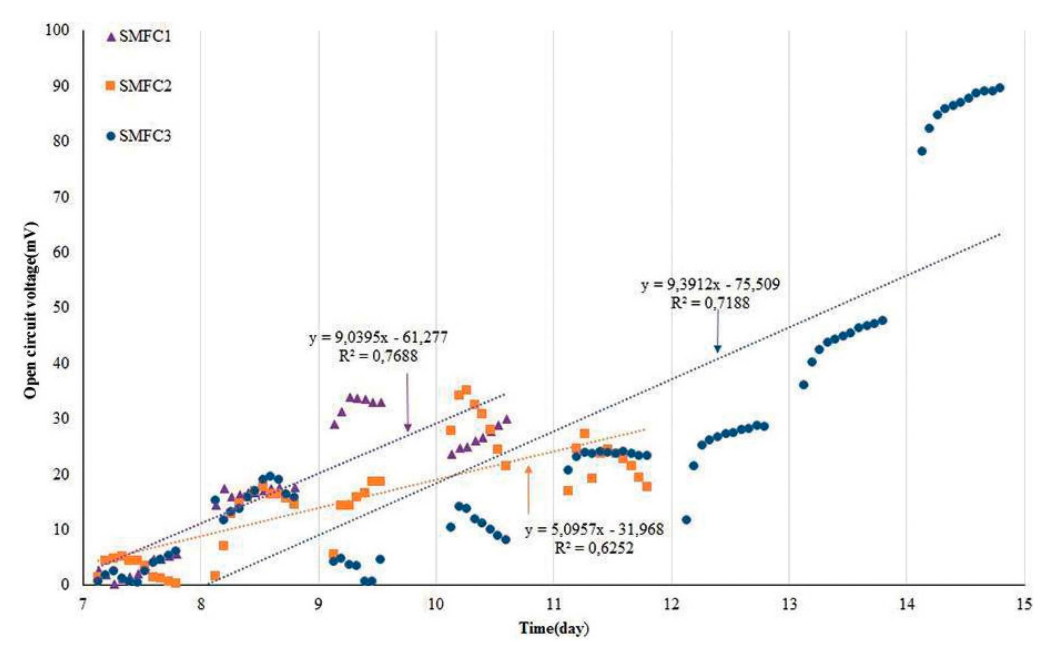

Figure 2. Linear increasing stage of the SMFCs before reaching the steady stage. 
According to Peixoto et al. 2011 [25] three similar OCVs are needed to consider a steady stage. In previous studies, where the MFCs were entirely exposed into an aqueous environment, 4 weeks [15], $46 \mathrm{~d}$ [8] have been required for reaching stable current and potential, respectively. Nevertheless, this study showed that the SMFCs required lesser time than previous studies for reaching a stable OCV output, and it was in dependent on the BOD concentrations. Thereby, SMFC1 reached it first, then SMFC2, however, SMFC3 was still in the increasing stage at the end of the elapsed time, therefore we assumed that the higher BOD concentration tested in SMFC3 caused this effect. Although the control SMFC reached stable OCVs, the measurements during each stable cycle differed each other (data not shown), suggesting that depletion of nutrients could cause this effect.

Figure 3 depicts the steady stage of the SMFCs inoculated with SRWW. The OCV intervals in this stage were between 40.6-58.8 $\mathrm{mV}$ and 18.2-32.9 $\mathrm{mV}$ for SMFC1 and SMFC2, respectively. In the meantime, the average OCV in this stage increased $97.82 \%$ and $32.20 \%$ from the last highest cycle of the increasing stage for SMFC1 and SMFC2, respectively. Results indicated that the OCV of SMFC1 was almost twice that of SMFC2, and required less time to reach the steady stage as well, therefore this suggested that the BOD concentration of the SRWW had the major influence on these terrestrial MFCs, as indicated in a previous report with aqueous MFCs [15]. Although mature biofilm is required for the MFC voltage performance, stability and reproducibility [8], the relative lower OCV in this stage could be caused by over-mature biofilm formation on the anode. Therefore this could reduce the extracellular electron transport to the anode electrode, however, stability was not affected. Moreover, the internal resistance of the SMFCs could be another influencing factor. In the case of the control SMFC the OCV decayed $86.89 \%$ from the last cycle in the increasing stage, therefore it was assumed that most of the soil nutrients were depleted. In addition, by contrast to SMFC1 and SMFC2, the control SMFC stabilized at the lowest OCV, likely caused by the fuel cell lack feedstock and the influence of mineral accumulation from the MW, both in the SMFC matrix.

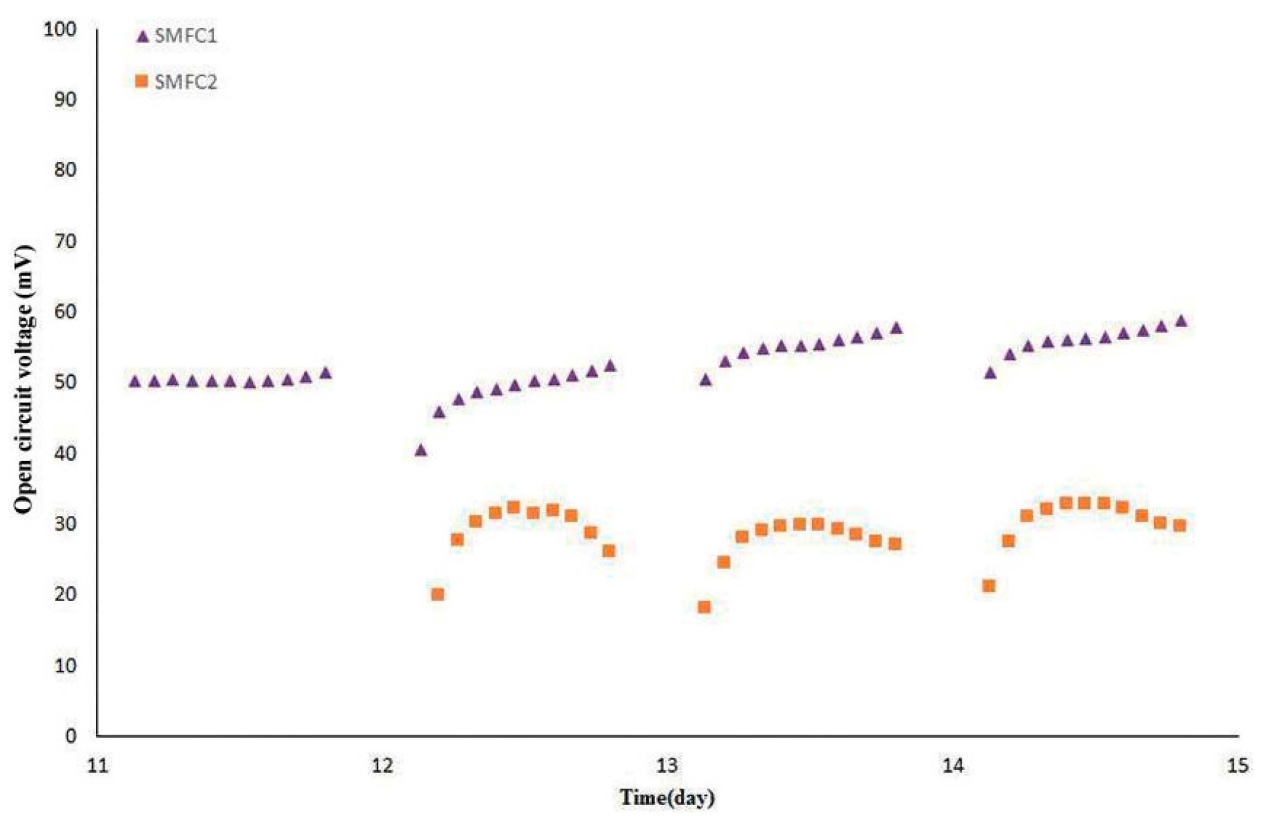

Figure 3. Steady stage and reproducibility of the SMFCs.

Reproducibility of the SMFCs was observed from day 12 and 13, in four and three cycles for SMFC1 and SMFC2, respectively. Before starting phase 2, after 6 days of SRWW flowing, the CFU/g soil was determined to be $1.2 \times 10^{11}, 4.0 \times 10^{12}, 3.0 \times 10^{11}$ for SMFC 1, SMFC2 SMFC3, respectively. Thereby, after six cycles of SRWW flowing through the SMFCs the CFU/g soil was consequently higher than the initial population and likely stable, therefore explaining the linear OCV increment. Figure 2 
illustrates the increasing stage of the OCV output with good linearity, due to the fact the number of cells in contact with the anode electrode is proportional to the OCV output [26].

In this study the initial $\mathrm{pH}$ of the soil was 5 (i.e., slight acidic). Therefore it was assumed that the microbial population in the SMFCs could be acclimatized to a slightly low $\mathrm{pH}$, although, other studies suggested that the $\mathrm{pH}$ should be controlled near neutrality in aqueous-MFCs [27]. In this case, by employing a slight low $\mathrm{pH}$ for the adapted microbial population could suggest an advantage, due to the fact acclimatized bacteria could respond earlier, generating the linear increase and steady stages in less time. Nevertheless, it could had some effect on the amount of OCV. Therefore, the major effect of the amount of voltage could be due to nutrient availability.

The results indicated that the SMFCs used in this study required less time to reach stable OCVs than MFCs inoculated with the same Andean soil and organic solid wastes [19,20]. This could suggest the better feasibility of these microorganisms to metabolize simple microbial fuels rather than complex ones. However, the microbial community with organic solid wastes $[19,20]$ showed higher OCVs output than SRWW, likely caused by the MFC design, and the overpopulation of microbes which preferred starch as carbon source, however this dominance could decrease the OCV output. In previous reports, where starch [28], swine [24], rice mill [27] and potato-processing [29] wastewaters have been tested in aqueous-MFCs high performance were achieved. Nevertheless, in this study the linearly increasing and stable OCVs were also reached, but in less time than for aqueous-MFCs. We highlight that the different design and complex matrix made it difficult to compare with other studies (aqueous-MFCs). However, although terrestrial MFCs have been widely tested for producing bioelectricity, through this preliminary investigation we propose their use as biosensors for evaluating BOD.

In the MFC-based biosensor technology parameters like reproducibility, high accuracy and low cost of the devices are important factors to be considered. The MFCs might be suitable devices for infield monitoring and for this one needs to take into account parameters like temperature, conductivity and $\mathrm{pH}$ as Peixoto et al. [25] reported. This preliminary study therefore presents terrestrial SMFCs as a useful possibility for environmental monitoring; for instance by using them as a BOD biosensor. Although, lower OCVs output performance were achieved in these MFCs, an increment of the electrical response by a power management system could be applied [18]. In addition, these MFCs depicted positive characteristics such as easy assembly process, lower time for reaching the steady stage and reproducibility for the BOD concentrations of SRWW.

\section{Conclusions}

This study shows that a terrestrial microbial fuel cell-based biosensor could be applied as an alternative setup for monitoring BOD in wastewater. The results indicated that this SMFC had a good and early response for reaching the steady stage and therefore the reproducibility for BOD concentrations lower than 200 ppm of SRWW. It was observed that higher concentrations of BOD required more time to reach the stable phase, suggesting this influencing factor as crucial for consideration in practical applications.

Acknowledgments: This work was supported by the Centro de Investigación de Energías Alternativas y Ambiente-Escuela Superior Politécnica de Chimborazo-Ecuador. The authors acknowledge to Gabriela Allauca for her help in the monitoring work.

Author Contributions: Washington Logroño, Alex Guambo and Celso Recalde designed and performed the experiment, and analyzed the data. Mario Pérez and Abudukeremu Kadier collaborated with analysis of data. The manuscript has been prepared with the contributions of all authors.

Conflicts of Interest: The authors declare no conflict of interest. 


\section{References}

1. Franks, A.E.; Nevin, K.P. Microbial Fuel Cells, A Current Review. Energies 2010, 3, 899-919. [CrossRef]

2. Chouler, J.; di Lorenzo, M. Water Quality Monitoring in Developing Countries; Can Microbial Fuel Cells be the Answer? Biosensors 2015, 5, 450-470. [CrossRef] [PubMed]

3. Pietrelli, A.; Micangeli, A.; Ferrara, V.; Raffi, A. Wireless Sensor Network Powered by a Terrestrial Microbial Fuel Cell as a Sustainable Land Monitoring Energy System. Sustainability 2014, 6, 7263-7275. [CrossRef]

4. Abrevaya, X.C.; Sacco, N.J.; Bonetto, M.C.; Hilding-Ohlsson, A.; Cortón, E. Analytical applications of microbial fuel cells. Part II: Toxicity, Microbial Activity and Quantification, Single Analyte Detection and Other Uses. Biosens. Bioelectron. 2015, 63, 591-601. [CrossRef] [PubMed]

5. Monier, J.M.; Niard, L.; Haddour, N.; Allard, B.; Buret, F. Microbial Fuel Cells: From Biomass (waste) to Electricity. In Proceedings of the 14th IEEE Mediterranean Electrotechnical Conference, MELECON, Ajaccio, France, 5-7 May 2008; pp. 663-668.

6. Logan, B.E. Exoelectrogenic bacteria that power microbial fuel cells. Nat. Rev. Microbiol. 2009, 7, $375-381$. [CrossRef] [PubMed]

7. APHA. Standard Methods for Examination of Water and Wastewater, 20th Edition American Public Health Association, American Water Works Association, Water Environment Federation; American Public Health Association: Washington, DC, USA, 1998.

8. Hsieh, M.C.; Chung, Y.C. Measurement of biochemical oxygen demand from different wastewater samples using a mediator-less microbial fuel cell biosensor. Environ. Technol. 2014, 35, 2204-2211. [CrossRef] [PubMed]

9. Kaur, A.; Kim, J.R.; Michie, I.; Dinsdale, R.M.; Guwy, A.J.; Premier, G.C. Microbial fuel cell type biosensor for specific volatile fatty acids using acclimated bacterial communities. Biosens. Bioelectron. 2013, 47, 50-55. [CrossRef] [PubMed]

10. Wang, J.; Zheng, Y.; Jia, H.; Zhang, H. Bioelectricity generation in an integrated system combining microbial fuel cell and tubular membrane reactor: Effects of operation parameters performing a microbial fuel cell-based biosensor for tubular membrane bioreactor. Bioresour. Technol. 2014, 170, 483-490. [CrossRef] [PubMed]

11. Liu, B.; Lei, Y.; Li, B. A batch-mode cube microbial fuel cell based "shock" biosensor for wastewater quality monitoring. Biosens. Bioelectron. 2014, 62, 308-314. [CrossRef] [PubMed]

12. Stein, N.E.; Hamelers, H.V.M.; van Straten, J.; Keesman, K.J. On-line detection of toxic components using a microbial fuel cell-based biosensor. J. Process. Control. 2012, 22, 1755-1761. [CrossRef]

13. Liu, Z.; Liu, J.; Zhang, S.; Xing, X.H.; Su, Z. Microbial fuel cell based biosensor for in situ monitoring of anaerobic digestion process. Bioresour. Technol. 2011, 102, 10221-10229. [CrossRef] [PubMed]

14. Kumlanghan, A.; Liu, J.; Thavarungkul, P.; Kanatharana, P.; Mattiasson, B. Microbial fuel cell-based biosensor for fast analysis of biodegradable organic matter. Biosens. Bioelectron. 2007, 22, 2939-2944. [CrossRef] [PubMed]

15. Chang, I.S.; Jang, J.K.; Gil, G.C.; Kim, M.; Kim, H.J.; Cho, B.W.; Kim, B.H. Continuous determination of biochemical oxygen demand using microbial fuel cell type biosensor. Biosens. Bioelectron. 2004, 19, 607-613. [CrossRef]

16. Di Lorenzo, M.; Thomson, A.R.; Schneider, K.; Cameron, P.J.; Ieropoulos, I. A small-scale air-cathode microbial fuel cell for on-line monitoring of water quality. Biosens. Bioelectron. 2014, 62, 182-188. [CrossRef] [PubMed]

17. Shen, Y.; Wang, M.; Chang, I.S.; Ng, H.Y. Effect of shear rate on the response of microbial fuel cell toxicity sensor to $\mathrm{Cu}(\mathrm{II})$. Bioresour. Technol. 2013, 136, 707-710. [CrossRef] [PubMed]

18. Zheng, Q.; Xiong, L.; Mo, B.; Lu, W.; Kim, S.; Wang, Z. Temperature and Humidity Sensor Powered by an Individual Microbial Fuel Cell in a Power Management System. Sensors 2015, 15, 23126-23144. [CrossRef] [PubMed]

19. Logroño, W.; Ramírez, G.; Recalde, C.; Echeverría, M.; Cunachi, A. Bioelectricity Generation from Vegetables and Fruits Wastes by Using Single Chamber Microbial Fuel Cells with High Andean Soils. Energy. Procedia. 2015, 75, 2009-2014. [CrossRef] 
20. Logroño, W.N.; Echeverría, M.M.; Recalde, C.G.; Graziani, P. Bioconversion of organic solid wastes with soils from the Amazonian and high Andean regions of Ecuador in single chamber microbial fuel cells. Inf. Tecnol. 2015, 26, 61-68. [CrossRef]

21. Sessitsch, A.; Weilharter, A.; Gerzabek, M.H.; Kirchmann, H.; Kandeler, E. Microbial population structures in soil particle size fractions of a long-term fertilizer field experiment. Appl. Environ. Microbiol. 2001, 67, 4215-4224. [CrossRef] [PubMed]

22. Jiang, Y.-B.; Deng, H.; Sun, D.-M.; Zhong, W.-H. Electrical signals generated by soil microorganisms in microbial fuel cells respond linearly to soil $\mathrm{Cd}^{2+}$ pollution. Geoderma 2015, 255-256, 35-41. [CrossRef]

23. Ringelberg, D.B.; Foley, K.L.; Reynolds, C.M. Electrogenic capacity and community composition of anodic biofilms in soil-based bioelectrochemical systems. Appl. Microbiol. Biotechnol. 2011, 90, 1805-1815. [CrossRef] [PubMed]

24. Min, B.; Kim, J.R.; Oh, S.E.; Regan, J.M.; Logan, B.E. Electricity generation from swine wastewater using microbial fuel cells. Water Res. 2005, 39, 4961-4968. [CrossRef] [PubMed]

25. Peixoto, L.; Min, B.; Martins, G.; Brito, A.G.; Kroff, P.; Parpot, P.; Angelidaki, I.; Nogueira, R. In Situ Microbial Fuel Cell-Based Biosensor for Organic Carbon. Bioelectrochemistry 2011, 81, 99-103. [CrossRef] [PubMed]

26. Lee, S.W.; Jeon, B.Y.; Park, D.H. Effect of bacterial cell size on electricity generation in a single-compartmented microbial fuel cell. Biotechnol. Lett. 2010, 32, 483-487. [CrossRef] [PubMed]

27. Behera, M.; Jana, P.S.; More, T.T.; Ghangrekar, M.M. Rice mill wastewater treatment in microbial fuel cells fabricated using proton exchange membrane and earthen pot at different $\mathrm{pH}$. Bioelectrochemistry 2010, 79, 228-233. [CrossRef] [PubMed]

28. Lu, N.; Zhou, S.-G.; Zhuang, L.; Zhang, J.T.; Ni, J.R. Electricity generation from starch processing wastewater using microbial fuel cell technology. Biochem. Eng. J. 2009, 43, 246-251. [CrossRef]

29. Durruty, I.; Bonanni, P.S.; González, J.F.; Busalmen, J.P. Evaluation of potato-processing wastewater treatment in a microbial fuel cell. Bioresour. Technol. 2012, 105, 81-87. [CrossRef] [PubMed]

(C) 2016 by the authors; licensee MDPI, Basel, Switzerland. This article is an open access article distributed under the terms and conditions of the Creative Commons by Attribution (CC-BY) license (http:/ / creativecommons.org/licenses/by/4.0/). 